\title{
Unusual Syllabification Among Nollywood Actors: A Perceptual Analysis
}

\author{
Dr. Nkereke M. Essien \\ Department of English, University of Uyo, Uyo, Nigeria
}

\begin{abstract}
This study examines the unusual syllabification among the Nollywood actors in their use of English while acting in various movies. The main purpose is to examine the cause of unusual syllabification that is usually observed among Nollywood actors. To carry out this analysis, a case study approach was used in the study and data were collected through playing and watching the movies. Attention was paid to unusual syllabification of words of different syllables by some actors. These words were jotted down and later analyzed by comparing them with actual syllabification using Longman Dictionary of Contemporary English which acts as the control. The theoretical framework used for the study is prominence/Sonority Theory with special emphasy on Sonority Sequencing Principles (SSP). Our finding revealed that there are instances of unusual syllabification of words by Nollywood actors.
\end{abstract}

Keywords: Nollywood, Prominence Theory, Syllables, Syllabification.

DOI: $10.7176 /$ JLLL/77-08

Publication date:March $31^{\text {st }} 2021$

\section{Introduction}

Non-native speakers of English such as Nigerians; and in this case, Nollyhood actors, are bound to experience challenges with English pronunciation due to inconsistencies between spoken and written English which accounts for wrong pronunciation of certain words by either extending or reducing some syllables in words. Therefore, this research is carried out to ascertain whether there are instances of unusual syllabification, during pronunciation by Nollywood actors.

Every English word consists of one or more syllables. A syllable or juncture is a combination or a set of one or more phonemes in a language consisting of a vowel with or without a consonant flanking the phoneme on either or both sides (Ufot 2009). A syllable is phonologically tonal or rhythmical unit of a word and a vowel phoneme is mandatory for a strong syllable. Syllable can be defined phonetically or phonologically. Technically, the basic phonetic constituents of the English syllable are the onset and the rhyme. The onset consists of one or more consonants before the vowels (that is the opening consonant of the syllable) while the rhyme (Rime) is further subdivided into the nucleus or peak (a vowel, regarded as the centre of the syllable) and codas. The syllable may be represented structurally thus:

Figure 1:

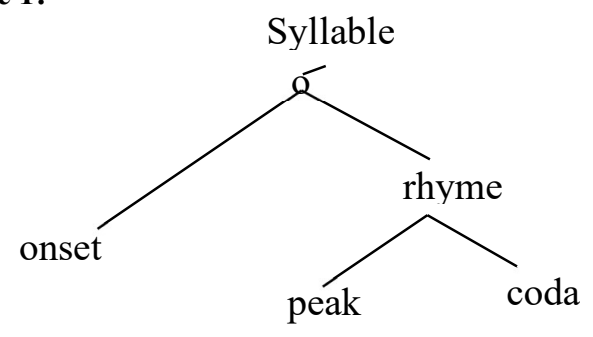

This type of branding is the most common across languages and English is not an exception. The syllable (conventionally marked as small Greek sigma (ó) has two constituents: the onset (ONS), which is the beginning of the segment, which includes the nuclear elements (the vowel) as well as any other element (consonants) what might follow it. Syllable structure is represented graphically by means of a tree diagram as shown below as in the word cat $/ \mathrm{kæt} /$. 
Figure 2:

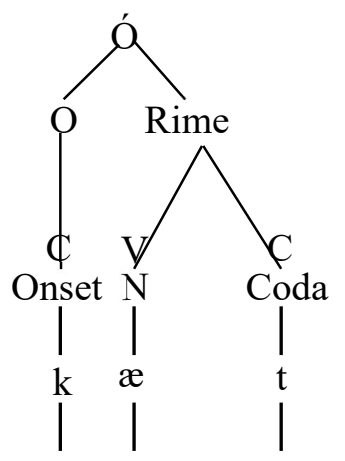

\subsection{Objectives of the Study}

The aims and objectives of this study include:

i. $\quad$ to identify what constitute a syllable.

ii. examine syllabification and what it entails.

iii. Investigate unusual syllabification among some Nollywood actors in the series under study.

iv. Examine the causes of extension or deduction of syllables by these actors and

v. Proffer solutions to the problem of unusual syllabification among Nollywood actors.

\subsection{Previous Knowledge on Syllabification}

For one to know whether there is unusual syllabification when words or utterances are made, it is pertinent to understand what syllabification is concerned with. Therefore previous knowledge or studies on syllabification is necessary as discussed below.

\subsubsection{Syllabification}

Literature related to this research is reviewed in this section. Many linguists have observed that there are many "unanswered questions" on how to decide on the division between syllables when we find a connected sequence of speech. For instance, Roach $(2010$; p.60) observes by looking at two words that are simple examples of the problem of dividing adjoining syllables. According to Roach English speakers feel that the word "morning" /mo:nis/ consists of two syllables, and suggested that we need a way of deciding whether the division into syllable should be "mว:" and "nin", or "mo:n" and "in". The source further observed a more difficult case as in the word "extra" /ekstrə/. He noted that the word "extra" has two syllables and controversially where the two syllables are to be divided, he presented some possibilities by using the symbol $(\bullet)$ to syllable boundary as follows:

1. /e.kstrə/

2. /ek.stra/

3. /eks.tra/

4. /ekst.re/

5. /ekstr.ə/ (p.61)

Since there is no single rule on the division of the syllable without bringing up problems, the source suggests that one of the most widely accepted guidelines is the "Maximal Onsets Principle which states that "where two syllables are to be divided, any consonants between them should be attached to the right-hand syllable, not the left, as possible" (p.61). By this rule, the word "extra" would be divided as in (i) /e.stra/ but Englis syllable does not begin with $/ \mathrm{kstr} /$. Roach further suggests that "our rule must therefore state that consonants are assigned to the right-hand syllable as far as possible within the restrictions governing syllable onset and coda". From this rule we have to reject (i) and (v) because of its impossible onset /e.kstrə/ and /ekstr.ə/ because of its impossible coda respectively while choosing (ii) /ek.strə/.

In his conclusion, he puts forward one possible solution to dividing syllables to it units by advising that "when one consonant stands between vowels and it's difficult to assign consonant to one syllable or the other - as in "better and carry" - we could say that the consonant belongs to both syllables". A consonant in this situation is referred to as ambisyllabic.

In discussing syllabification Katamba, (1997:161) explains that a theory has to provide a way of grouping arrays of CV elements into syllables in situations where we have VCVCCCVC. Katamba asked "to which syllable node are $\mathrm{C}$-elements assigned in ambiguous cases, where they would go with either the preceding or the following vowel?" and also questions "to which syllable, should the middle consonant of 'panic' (CVCVC) be arranged".

According to Katamba, the Onset First Principle in (Khan 1976, Clement and Keyer 1983) has been proposed to handle this kind of situation which this research also subscribes. It states that:

a. "Syllable-initial consonants are maximized to the extent consistent with the syllable structure conditions of the language in question. 
b. Subsequently, syllable - final consonant are maximized to the extent consistent with the syllable structure of the language in question (Clements and Keyser 1983 in Katamba 1997:161).

Katamba further explains that principle (a) applies before (b) in any derivation and observes that in potentially ambiguous cases, initial consonant clusters take precedence over syllable final ones. By implication according to Katamba, given a string-like VCV, the Onset First Principle requires that the string be divided up a V-CV rather than VC-V. He gives an instance of a word like 'ever' [evə] is divided up as [e-və]. Presenting another example Katamba says that English allows CC sequence like [sp] which can occur in the initial environment as in "spoon" or at final as in "grasp". He concludes that in a word like "aspire" where the [sp] cluster could be regarded as syllable initial or initial, the word can be syllabified as either as-pire or asp-ire. This according to Katamba "The Onset First Principle predicts that the former is the correct syllabification.

\subsubsection{Fundamental Rules of Syllabifications}

i). Syllabification should be governed not by etymology but by pronunciation. Thus we should divide 'pe-ruse', not 'per-use'.

ii). To find the number of syllable:

* count the vowels in the word,

* subtract any silent vowel, (like the silent "e" at the end of vowel or the second vowel when two vowels are together in syllable).

* subtract one vowel from every diphthong (diphthongs only count as one vowel sound).

* the number of vowels sounds left is the same as the number of syllables. The number of syllables that one hears when pronouncing a word is the same as the number of vowels sounds heard. For example the word "came" has two vowels, but the /e/ is silent, leaving one vowel sound and one syllable. The word "outside" has (4) four vowels but the /e/ is silent and the / $/ \alpha v /$ is a diphthong which counts as only one sound. So this word has only two vowels sounds and therefore two syllables.

iii). In words ending in double consonants, the consonants should not be separated in syllabifying their derivatives- fall, fall-en; miss, miss-ing, pass, pass-ive.

iv). Dissyllabic terminations that are sounded as one syllable should be so divided as fam-il-iar, po-ten-tial, re-gion, o-cean etc.

v). Divide between two middle consonants split up words that have two middle consonants. For example hap-pen, bas-ket, let-ter, sup-er, din-ner and Den-nis. The only exceptions are consonant digraphs as they really represent only one sound. The exceptions are "th", "sh", "ph", "ch" and "wh".

vi). Usually divide before a single middle consonants. When there is only one syllable, one usually divides in front of it as in 'o-pen, i-tem, e-vil, and re-port'. The only exceptions are those times when the first syllable has an obvious short sound as in 'cabin'.

vii). Divide before the consonant, before an '-le syllable. When you have a word that has the old style spelling in which "-le" sounds like "-el”, divide before the consonant before the "-le". For instance; 'a-ble', 'stumble', 'mum-ble', and 'this-tle'. The only exception to this are '-ckle' in words like 'tickle'.

viii). Divide off any compound words, prefixes, suffixes and roots which have vowel sounds. Split off the parts of compound words like "sports-car" and "house-boat". Divide off prefixes such as "un-happy, pre-paid, re-write". Also divide off suffixes as in the words 'farm-er, teach-er, hope-less and care-ful'. In the word "stopping", the suffix is actually "-ping" because this word follows the rule that when you add "-ing" to a word with one syllable, you double the last consonant and the "-ing".

\subsection{An Overview of Nollywood}

The movie industry in Nigeria is a lucrative but hectic terrain. If one works hard enough at it, and he/she will be able to gradually, but painstakingly get to the top. The Nigerian movie industry also takes the sobriquet. Nollywood, a term coined perhaps, to help distinguish them from other woods such as the Hollywood etc. This term is believed to have sprung up in early 2000 (Wikipedia).

The Nollywood stars use the Standard British English as their medium for acting as well as for interacting. Though a lot of them use the British Standard language as the ideal, yet practically, a lot resort to the Nigerian English which they speak with the Nigerian accent. Many of these actors speak with both local and foreign accent (like the half cast). The Nollywood is heavily characterized also by local playlets/soap operas in the local language such as the Igbo, Hausa, Yoruba, Ibibio, Efik languages etc. These actors also play roles which require the use of pidgins or creoles.

Due to the platform of mother tongue interference, from their indigenous language s into English, language (their L2) a lot of them usually battle with some words in English. There is the common occurrences of epethentis, a linguistic situation where extra sounds are added to the existing sounds in a word in the course of pronouncing it. For instance, where the word syringe /sring/, pronounced as /SI:rin/, others include; strap /strap/ pronounced as /starap/ etc. in some cases elision, deletion may be used. 


\subsection{Research Methodology}

This work will take both quantitative and qualitative approaches in understanding the unusual syllabification among Nollywood actors. The qualitative approach will require the use of published materials on the subject, while the quantitative will require the use of data obtained from selected actor's conversation electronically. A total of twenty actors are picked online; three movies were played and listened to. Three Nigerian movies titled "The Johnson", "The Maid" and "Isakaba" were played. The actor's utterances were listened to and written down. Their voices were also recorded. The test items were twenty (20) words of different syllabification. These words were later compared with the actual syllabification in the Longman Dictionary of Contemporary English. This Dictionary was chosen because words are broken down into their syllabic units.

\subsection{Theoretical Framework}

This paper adopts the Prominence Theory. This theory was put forward by O'Jesperson (1904) and further developed by other Western linguists. Another name for this theory is "Sonority Theory". By the term sonority, it means prevalence in a speech sound of musical tone over noise (hence the word Sonorant). In this theory, sonority is used in the meaning which is conveyed by the precise acoustic term "carrying power". Sonority theory is based upon the fact that each sound has a different carrying power.

According to Ojarikere (2007:182), prominence is determined by sonority. They stand out from other sounds in the perception of the listeners. In this way, we have peaks of prominence or syllabicity. The peaks form the syllables, while non-peaks form the boundaries. In any sequence the most sonorous sounds tends to form the centre of the syllable and the least sonorous, the marginal segments; a syllable contains one peak of sonority (or prominence).

This theory is relevant to this study, in that it will help in studying syllabification among the target audience. It will enable the researcher to know whether there is unusual syllabification among the Nollywood actors, since it is a very good method of breaking words down into syllables.

\subsection{Discussion}

\subsection{Data Presentation}

Tables 1 below shows the syllabification of words of all syllabic types as used from the Longman dictionary and the unusual syllabification by the Nollywood actors.

From the data presented in Table 1, observation show that unusual syllabification was observed in all syllable types - monosyllabic words, bisyllabic words, polysyllabic words and extrasyllabic words. Slight alternatives were also experienced in their communications.

Table 1: Control's (Longman Dictionary/Syllabification of Words of Different Types of Syllable

\begin{tabular}{|c|c|c|c|c|}
\hline Respondents & $\begin{array}{c}\text { English Words } \\
\text { Item }\end{array}$ & $\begin{array}{c}\text { Longman Dictionary } \\
\text { Syllabification (Control) }\end{array}$ & $\begin{array}{c}\text { Unusual } \\
\text { Syllabification }\end{array}$ & Transcription \\
\hline 1 & Open & o-pen & op-en & /əU.pən/ \\
\hline 2 & missing & miss-ing & mi-ssing & /mis.ị/ \\
\hline 3 & Super & su-per & sup-er & /su:.po/ \\
\hline 4 & teacher & teach-er & tea-cher & /ti:t3.ə/ \\
\hline 5 & correct & cor-rect & co-rrect & /kə.rekt/ \\
\hline 6 & encounter & en-coun-ter & en-counter & /iń.kaun.tə/ \\
\hline 7 & quantity & quan-ti-ty & qaunti-ty & /kwan.tə.ti/ \\
\hline 8 & opportune & op-por-tune & opp-or-tune & /ap.ə.tju:n/ \\
\hline 9 & curiosity & cu-ri-os-si-ty & cu-rio-si-ty & /kjuə.riu.sə.ti/ \\
\hline 10 & potential & po-ten-tial & po-te-ntial & /pə.ten. $\int 1 /$ \\
\hline 11 & individual & in-di-vi-dual & in-divi-dual & /in.di.vi.dzuəl/ \\
\hline 12 & eternity & e-ter-ni-ty & eter-nity & /itz:nəti/ \\
\hline 13 & intelligent & in-tel-li-gent & i-nte-lli-gent & /in.te.li.dzənt/ \\
\hline 14 & alligator & al-li-ga-tor & alli-ga-tor & /æ.li.gei.tə/ \\
\hline 15 & independent & in-de-pen-dent & i-nde-pendent & /in.di.pen.dənt/ \\
\hline 16 & identification & i-den-ti-fi-ca-tion & ide-nti-fica-tion & /ai.den.ti.fi.kei.jn/ \\
\hline 17 & termination & ter-mi-na-tion & ter-mina-tion & /tz:.mi.ńei.fn/ \\
\hline 18 & personification & per-soni-fi-ca-tion & per-so-nifi-ca-tion & /pə.sə.ni.fi.kei.jn/ \\
\hline 19 & fundamentally & fun-da-men-tal-ly & fu-nda-men-tal-ly & /fın.də.men.ta.li/ \\
\hline 20 & syllabification & syl-labi-fi-ca-tion & sylla-bi-fi-ca-tion & /si.læ.bi.fi.kei.fn/ \\
\hline
\end{tabular}




\subsection{Data Analysis}

\subsubsection{Statistical Analysis}

From table 1, column 3 depicts unusual syllabification perceptually. Simple percentage is used to compare the score, the performances of the subjects and the Longman dictionary syllabification. As for as the table shows, there are marked differences between Longman dictionary and the subjects unusual syllabification as they are clearly shown in Tables 2,3,4 and 5 below.

Table 2: Test on Normal Syllabification and Unusual Syllabification

\begin{tabular}{|c|c|c|c|c|}
\hline Respondents & $\begin{array}{c}\text { English Words } \\
\text { Item }\end{array}$ & $\begin{array}{c}\text { Longman Dictionary } \\
\text { Syllabification } \\
\text { (Control) }\end{array}$ & $\begin{array}{l}\text { Subject Unusual } \\
\text { Syllabification }\end{array}$ & Transcription \\
\hline 1 & open & o-pen & op-en & /aU.pən/ \\
\hline 2 & missing & miss-ing & mi-ssing & /mis.in/ \\
\hline 3 & super & su-per & sup-er & /su:.po/ \\
\hline 4 & teacher & teach-er & tea-cher & /ti:t3.ə/ \\
\hline 5 & correct & cor-rect & co-rrect & /kə.riekt/ \\
\hline 6 & encounter & en-coun-ter & en-cou-nter & /iń.kaun.tə/ \\
\hline 7 & quantity & quan-ti-ty & qaunti-ty & /kwan.tə.ti/ \\
\hline 8 & opportune & op-por-tune & opp-or-tune & /ap.ə.tju:n/ \\
\hline 9 & curiosity & curi-os-si-ty & cu-rio-si-ty & /kjuə.riu.sə.ti/ \\
\hline 10 & potential & po-ten-tial & po-te-ntial & /po.ten. $\int 1 /$ \\
\hline 11 & individual & in-di-vid-ual & in-di-vi-dual & /in.di.vi.dzuəl/ \\
\hline 12 & eternity & e-ter-ni-ty & eter-nity & /itz:nəti/ \\
\hline 13 & intelligent & in-tel-li-gent & in-te-lligent & /in.te.li.dzənt/ \\
\hline 14 & alligator & al-li-ga-tor & alli-ga-tor & /æ.li.gei.tə/ \\
\hline 15 & independent & in-de-pen-dent & i-nde-pendent & /in.di.pen.dənt/ \\
\hline 16 & identification & i-den-ti-fi-ca-tion & ide-nti-fica-tion & /ai.den.ti.fi.kei.Jn/ \\
\hline 17 & termination & ter-mi-na-tion & Ter-mina-tion & /tz:.mi.ńei.jn/ \\
\hline 18 & personification & per-soni-fi-ca-tion & Per-so-nifi-ca-tion & /pəsbnifikeifn/ \\
\hline 19 & fundamentally & fun-da-men-tal-ly & Fu-nda-men-tal-ly & /fın.də.men.ta.li/ \\
\hline 20 & syllabification & syl-labi-fi-ca-tion & Sylla-bi-fi-ca-tion & /si.læ.bi.fi.kei.jn/ \\
\hline
\end{tabular}


Table 3: Analysis of Respondents Comparative Unusual Syllabification

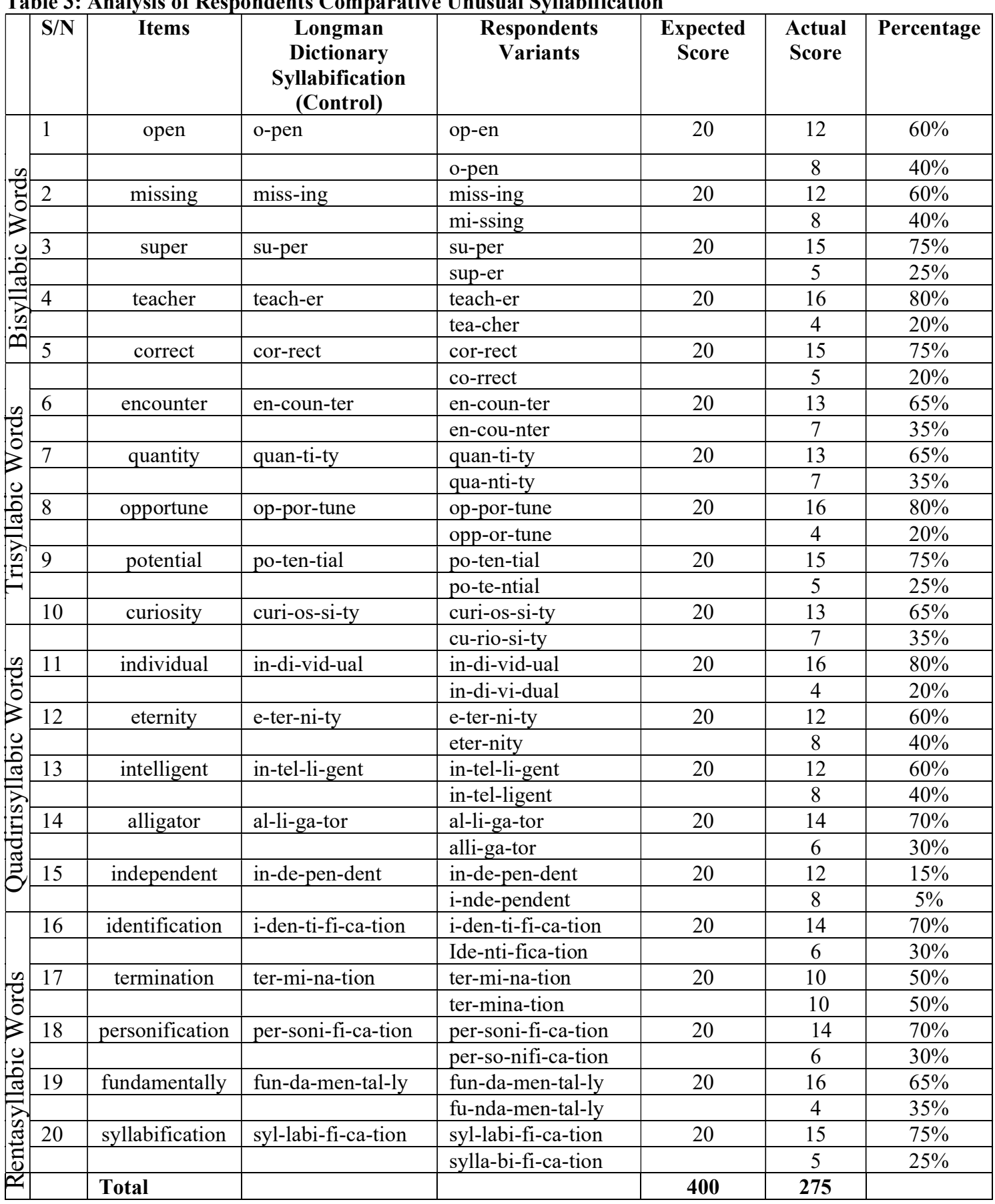

Table 4: Respondents Overall Comparative Unusual Syllabification of Syllables

\begin{tabular}{|l|c|c|}
\hline Overall Analysis of Tokens & & Percentage Score \\
\hline Overall percentage score & 400 & $100 \%$ \\
\hline Respondents overall score for unusual syllabification & 275 & $69 \%$ \\
\hline Respondents overall score for usual syllabification & 125 & $31 \%$ \\
\hline
\end{tabular}

The data presented in Table 2 and 3 typifies the respondents actual overall score is 275 . The syllabification of the words through the process of bisyllabification which is (30) tokens of expected (100) while trisyllabification is (30) token of (100) anticipated. Polysyllabification and bysyllabification was (40) and (31) respectively. For all syllabification, the percentage scores are therefore $(30 \%),(30 \%),(40 \%)$ and $(31 \%)$ respectively. 


\subsubsection{Application of Prominence/ Sonority Theory Analysis}

This study deploys the prominence Theory to account for the usual and unusual syllabification in the speech of the respondents. We shall represent this structurally using Tree diagrams for the bisyllabic, trisyllabic, quadirisyllabic, pentasyllabic word open/ə-pən/.

Open /ə- pən/

Figure 3a) Usual syllabification of "open" /ə-pən/

3b) Unusual Syllabification of "open"/əp-ən/
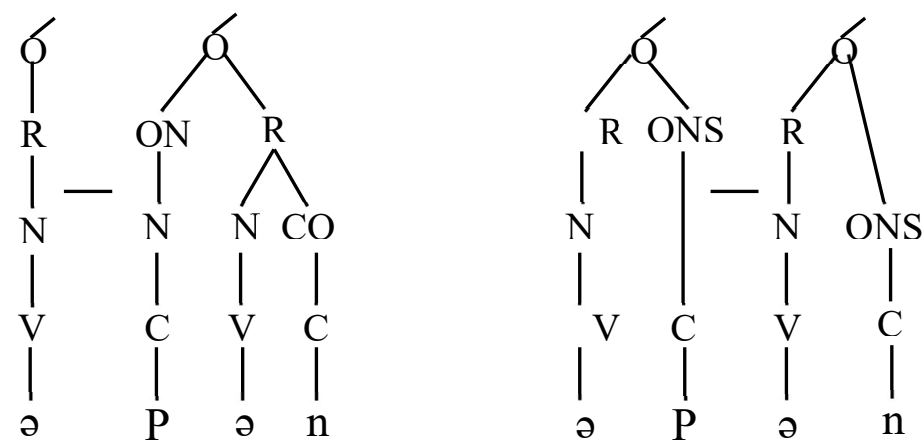

From the structures above, figure (a) and (b) are used to analyze the usual and the unusual syllabification of the word "open". It could be observed that usual syllabification for the word "open" has two syllables as "ə-pen", (V-cvc) while the unusual syllabification in figure (b) shows (әp-ən).

\section{Trisyllabic Words - Encounter /i $\eta$ kauntə/}

Figure 4a: Usual Syllabification of encounter

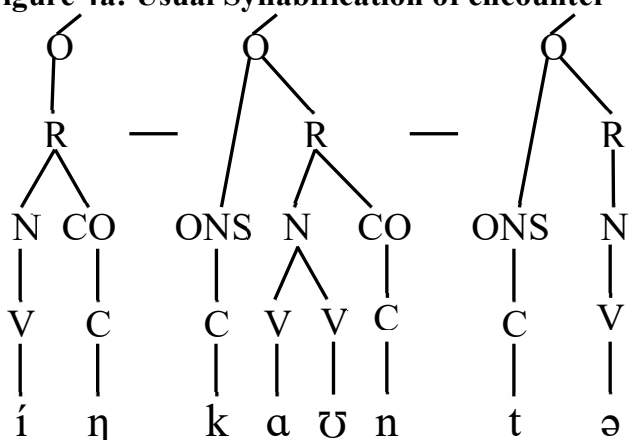

4b) Unusual Syllabification of encounter /i-nkaซ-ntə/

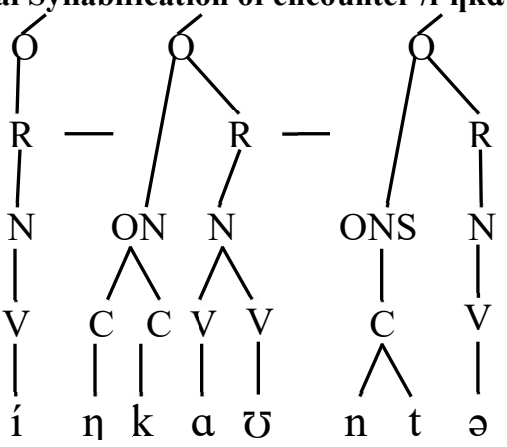

For the trisyllabic word "encounter", though both usual and unusual syllabification show the word being syllabified into three, the unusual one in figure (b) shows that in the third syllable, the onset begins with " $\mathrm{nt}$ " which does not hold for English words - that it does not follow the rules of syllabification in English. This may be due to the mother tongue of the respondents.

From the tree diagrams used to analyse the usual and the unusual word "fundamentally". It could be observed that the usual and the unusual word have five syllables respectively. The only difference is in the second and the third syllable onsets where we hard "dn" and "nt" which is not usually obtainable in English onset positions, hence the unusual syllabifications. 
Figure 5a: Usual Syllabification of the Word Intelligent - inte - lli - gent<smiles>CO</smiles><smiles>COC</smiles><smiles>[R]C([N])[O-]</smiles>
$\mathrm{ON}$<smiles>[R]C(C)C</smiles>

$\mathrm{N}$<smiles>OCCOCI</smiles><smiles>C[O-]</smiles>
$\mathrm{R}$<smiles>CO</smiles><smiles>C1CCC1</smiles><smiles>[R]1CC1</smiles><smiles>[AlH2]</smiles>

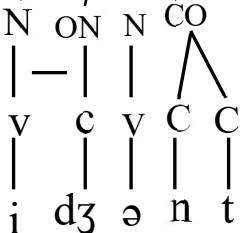

Figure 5b: Unusual Syllabification of the Word Intelligent

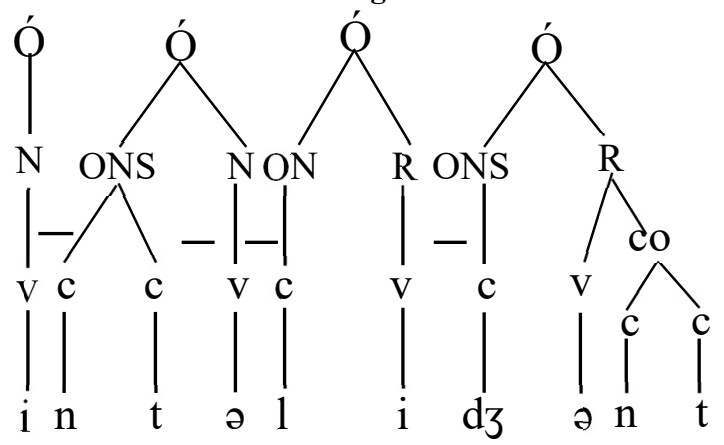

Figure 6a: Usual syllabification of the word Fundamentally Fun-da-men-tal-ly

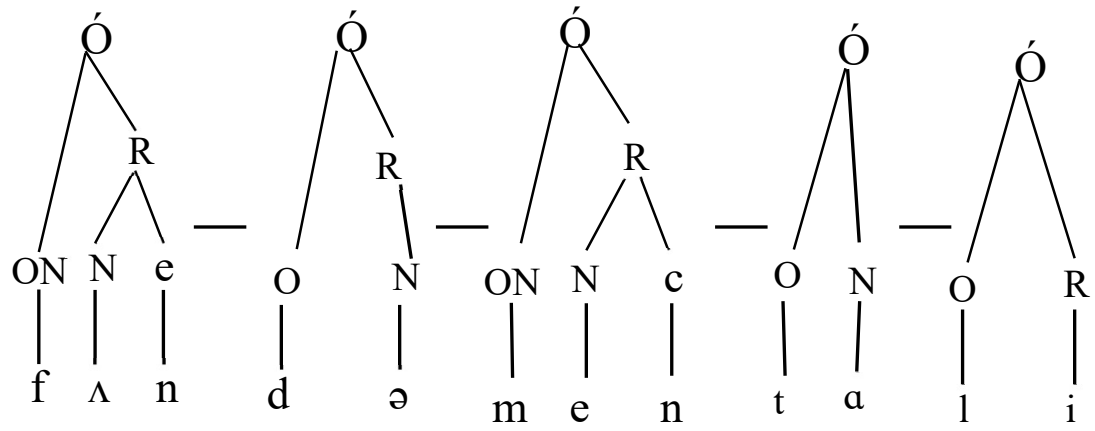

6b: Unusual syllabification of the word Fundamentally Fun-da-men-tal-ly

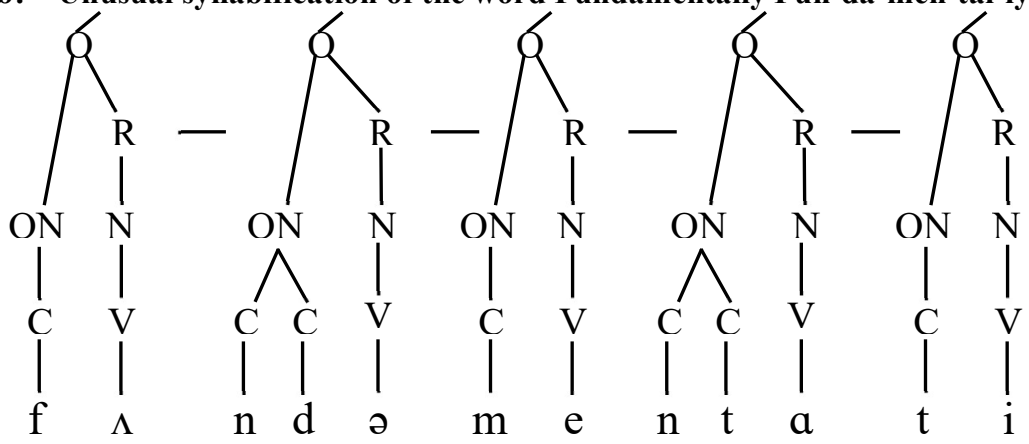

\section{Conclusion}

Pronunciation is an important criterion in the word division and once this is not done properly, there is the tendency or misappropriating meaning by the listener. The factors used in this study to gather data for the study indicate that they do not have adequate knowledge of syllabification of words. What results from this is the bastardize English and vocabulary according to Ekah (2016). This is detrimental to the viewing populace that are made up of young and old who feel that anything on television is a standard norms.

These findings of the results have been able to reveal that some Nigerian actors do not pay attention to syllabification in their communication when acting. During the course of acting, they either reduce some syllable or extending them (syllables). Again there is the problem of mother tongue interference, and accent social status. Also is the fact that because English allows unusually long onsets and codas, non-naïve speakers of English often subject syllable with long onsets and codas to processes that make them more like their native language. The study therefore concludes that the leaders of the Nigerian movie industries should organize workshops and seminars for their actors in the area of speech, production so that they can imbibe the standard variety of English.

\section{References}

Eka, D. (1996). Phonological Foundation: English. Uyo: Scholars Press (Nig) Ltd. 
Ekah, M. E. (2016). Phonographological problems of Ibibio-English bilinguals. In. S. T. Babatunde, U. E. Josiah and Ekah, M. E. (Eds) English language and literature in non-native environments: Issues patterns and preferences. A frestcript in honour of Professor David Jowitt (PP. 195-208) Ilorin: Haytee Press and Publishing Co. Nig. Ltd

Essien, N. M. (2016). English clusters and the $\mathrm{L}_{2}$ learners: Challenges of Intelligibility among Ibibio speakers. In S. T. Babatunde, U. E. Josiah and M. E. Ekah (Eds). English language and literature in non-native environment: issues patterns and preferences. A frestcript in honour of Professor David Jowitt (PP. 209-222). Ilorin: Haytee Press and Publishing Co. Nig. Ltd.

Ewen, C. J. and Harry van der Hulst (2001). The Phonological Structure of words. Cambridge University Press. Katamba, F. (1997). An introduction to phonology. London: Longman.

Ojurikere, A. (2007). Perspectives and problems of theorizing the English syllable Journal ofhumanities. 12, 179188.

Procter, P. (2014). Longman Dictionary of Contemporary English (6th edition) Edinburahi Pearson Edu. Ltd.

Roach, P. (2009). English phonetics and phonology: A practical course. Fourth Edition. Cambridge: Cambridge University Press.

Ufot, B. (2009). Modern English Structure. Uyo; Robertminder International Limited.

www.enq-literature.com retrieved 20 January, 2020. 8.44am. 